\title{
"Parrilla urethra": A sequalae of electric shock torture to genitals in men. A 40 case series in Kashmir (India)
}

\author{
Abdul Rouf Khawaja', Manzoor Dar², Yasir Dar³, Javeed Magray4, \\ Tariq Sheikh5, Suhail Zahur ${ }^{6}$
}

\begin{abstract}
Introduction: Since the 20th century, electric shock torture has become one of the most prevalent methods of torture partly because it produces sequelae that are more challenging to visibly detect, particularly when administered using high voltage and low current. In sexual torture, a wire is wrapped around the head of the penis and a wire electrode is inserted into the urethra. This produces unbearable pain and can lead to urethral strictures with devastating physical and psychological consequences.
\end{abstract}

Objective: To document electric shock torture to genitals as an etiologic agent in urethral stricture and erectile dysfunction amongst survivors of electric torture introducing the term "parrilla urethra" for the electric shock torture urethral stricture.

Materials and methods: The study included 40 patients who attended the Department of

1) Department of Urology. Directorate of Health Services Srinagar, 190011. India.

Correspondence to: roufkhawaja@rediffmail.com

2) Delhi University Correspondence to: drmanzoor996@gmail.com

3) Institute of Urology Dhule Mumbai. Correspondence to: yasserahmad009@gmail.com

4) Directorate of Health Services Kashmir. Correspondence to: drjavaid82@gmail.com

5) Directorate of Health Services Kashmir. Correspondence to: drtariq.sheikh@gmail.com

6) Directorate of Health Services Kashmir. Correspondence to: suhaelz@gmail.com
Urology, Directorate of Health services, Srinagar, Kashmir, India with obstructive lower urinary tract symptoms (LUTS) / obstructive uroflowmetry between March 2010 and November 2014. All cases had an antecedent of electric shock torture to genitals six months to one year prior to examination. Pre-post psychological impact and well-being was used through Global Assessment of Functioning (GAF) scores.

Results: The mean age of patients was 35.6 years. Most of the urethral strictures were located in the anterior urethra. Some degree of erectile dysfunction was present in all $(100 \%)$ of patients. Psychological sequelae including depression, anxiety, acute stress disorder and symptoms of post-traumatic stress disorder were observed. Patients were treated with standard urethroplasty procedures after addressing the urethral stricture. This improved both physical and psychological sequelae of torture.

Keywords: electric shock; parrilla; torture; urethral stricture

\section{Introduction}

The Kashmir region is a geographical area split between Indian, Pakistani and Chinese jurisdiction, that has suffered from protracted political conflict and where ill-treatment and torture has been widely documented (Deol \& Ganai, 2018; Haq, 2017, 2018; Human Rights 
Watch, 1993; Institut of Strategic Studies, 2019; JKCCS, 2019). In many of the reports available there have been reports of electric torture (Amnesty International, 1995; Deol \& Ganai, 2018; Haq, 2017; Human Rights Watch, 1993; Tahir Tabassum, 2012).

Electrical injury is a physiological reaction caused by electric current passing through the human body (Rybarczyk et al., 2017). Electric shock torture is widespread with Amnesty International (1997) finding that electric shock torture and ill-treatment have been reported in 62 countries in the period 1990-1997, and is commonly used by law enforcement officers with easily concealable, electro-shock weapons (TASERs and similar devices) (Amnesty International, 1997). Electric shock torture has become one of the most prevalent methods of torture since the $20^{\text {th }}$ century, partly because it produces sequelae that are more challenging to detect visibly, particularly when administered using high voltage and low current. The method therefore assists perpetrators with circumventing the negative political consequences posed by human rights monitoring mechanisms and from human rights advocates discovering and reporting torture (Amnesty International, 1997). One particular form of electric shock torture is parrilla torture. Parrilla, a term that stems from the Spanish word meaning a grill or barbeque for cooking meat, is a method of torture in which a victim is strapped to a metal frame and subjected to electric shock torture (Gómez-Barris, 2009). This torture method produces devastating psychological and physical consequences. The method was used by a number of countries in South America, including during the "dirty war" (1974-1983) in Argentina and in Chile during the Pinochet regime (1973-1990) as an interrogation method (Villani, 2011).

The three major mechanisms of electrical injuries are direct tissue damage, thermal injury and mechanical injury (Dzhokic"et al., 2008). However, virtually every part of the body can be injured by the electric current and the extent of injury to body tissue is influenced

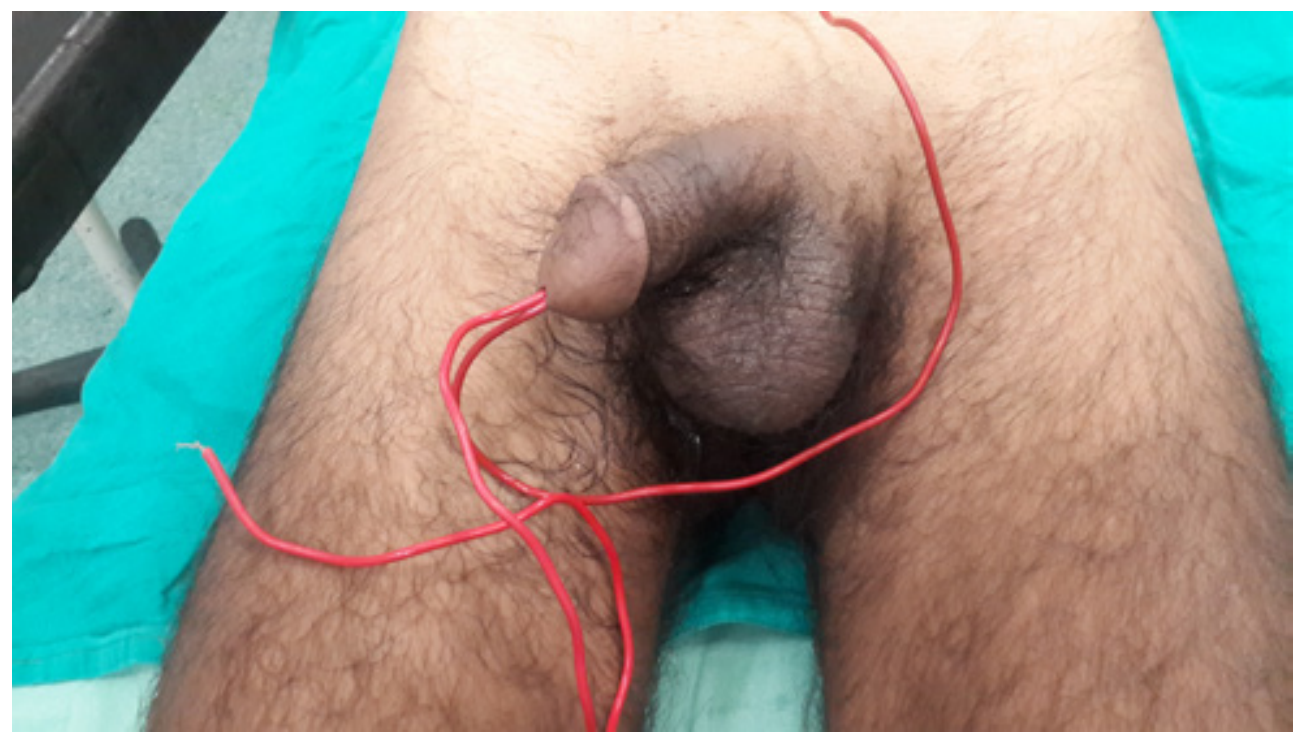


by a plethora of factors, including the type of body part targeted, the number of torture episodes, the duration of each torture episode, and the strength of the electric current. Alternating current (AC) is three times more dangerous than direct current (DC) of the same voltage. Nerves, muscles, and blood vessels have lower resistance and are better electrical conductors compared to bone, tendon and fat with nerve tissue having the least resistance to current flow, and are thus more susceptible to damage (Dzhokic et al., 2008).

Commonly, bare wire electrodes are applied to or inserted into different sensitive body parts, including genitalia, breasts, buttocks, fingers, toes, tongue, and head. For males, during electric torture to genitals, the fixed wire is wrapped around the head of the penis and a bare wire is inserted into the urethra. This results in mechanical urethral trauma in addition to electric injury to the urethra and other tissues. Some victims may consequently develop obstructive voiding symptoms and erectile dysfunction depending on the severity of the torture episode(s).

The most frequent psychological sequelae include sleep disturbances, being uncomfortable in situations reminding of past torture experiences, stigma and social isolation, ruminations about traumatic events, emotional instability and violence towards family members and suicidal attempts (Araujo et al., 2019; Ba \& Bhopal, 2017; Crescenzi et al., 2002; Cunningham \& Cunningham, 1997; Masmas et al., 2008; Suhaiban et al., 2019; Tamblyn et al., 2011).

Although electric torture to genitals has been previously described (i.e. Iran Human Rights Documentation Center, 2011; Weishut, 2015), no known research exists that investigates the sequelae and optimum rehabilitation procedures for patients presenting with ure- thral sequelae. This paper aims to help address this gap with two objectives:

1. To describe electric shock torture as an aetiological factor for urethral strictures and erectile dysfunction.

2. To introduce the term "parrilla urethra" into the literature for the urethral stricture disease resulting from electric shock torture to genitals.

\section{Methods and materials}

Sample. Survivors of electric shock torture $(n=40$, age $28-60$ years) presenting with urethral strictures at a Directorate of health care centre in Kashmir, India, between March 2010 and November 2014. All the patients included were from Kashmir valley (India) and had suffered torture at the hands of security personnel/armed groups as per narrated in clinical alleged history to our initial examination. We did not assess who was responsible for the violence because it was not relevant for our medical needs assessment.

Methods. Patients were self-referred or referred by human rights organizations. There was not a full systematic medical exploration of torture although patients were referred to other services in the hospital when required. Torture was defined using the Convention against Torture (UN General Assembly, 1984). All patients had a history of trauma inflicted upon the urethra via electric shock six months to one year prior to presentation. Patients with earlier lower urinary tract symptoms and any past history of urethral instrumentation were excluded from the study.

Erectile dysfunction was measured using the International Index of Erectile Function (IIEF-5) (Rosen et al., 1999; Rosen et al., 1997). It is a 5-item measure, each one scored from 1 to 5 and giving a composite score of 
5-25. The patients were classified as having no ED (22-25), mild ED (17-21), mild to moderate ED (12-16), moderate ED (8-11) and severe ED (5-7).

Retrograde and micturating cystourethrogram testing were obtained in all patients to determine stricture location and length.

Patients were screened for psychological consequences as part of the standard clinical interview and referred to psychiatric assessment when required.

The Global Assessment of Function (GAF) was used as a WHO recommended overall measure of global mental health and functional impact of psychological symptoms. This is a Likert-scale ranked 0 to $100 ; 100$ being optimal functionality (Aas, 2011).

Ethical elements. The study was approved by the departmental committee that also looks into ethical aspects of biomedical research conducted in the department. This being a retrospective audit of the anonymised records, the committee did not deem it necessary to refer the study to the main institutional ethics committee (IEC) as there was no ethical issues involved and hence exempt from ethical review.

\section{Results}

Pre-operative data. The stricture length ranged from $4 \mathrm{~cm}$ to $12 \mathrm{~cm}$ with a mean of $6.8 \mathrm{~cm}$ affecting the bulbar $(n=22)$, penobulbar $(n=7)$, and penile $(n=6)$ urethra. In 5 cases there was pan-urethral damage (table 1). 28 patients had a history of painful acute urinary retention (AUR). All patients also had erectile dysfunction secondary to electric shock as defined by IIEF-5 Scores 12 patients had severe ED, 21 had moderate ED, and 7 patients had mild to moderate ED. A subsection $(n=16)$ patients also had uncontrollable urine loss which was the result of overflow incontinence from chronic retention or a result of detrusor overactivity. An obstructive pattern was observed on uroflowmetry in all patients.

Psychological sequelae including anxiety, acute stress disorder/post-traumatic stress dis-

Figure 1. Anterior urethral stricture due to electro shock weapon (Parrilla Urethral stricture). Arrow showing stricture.

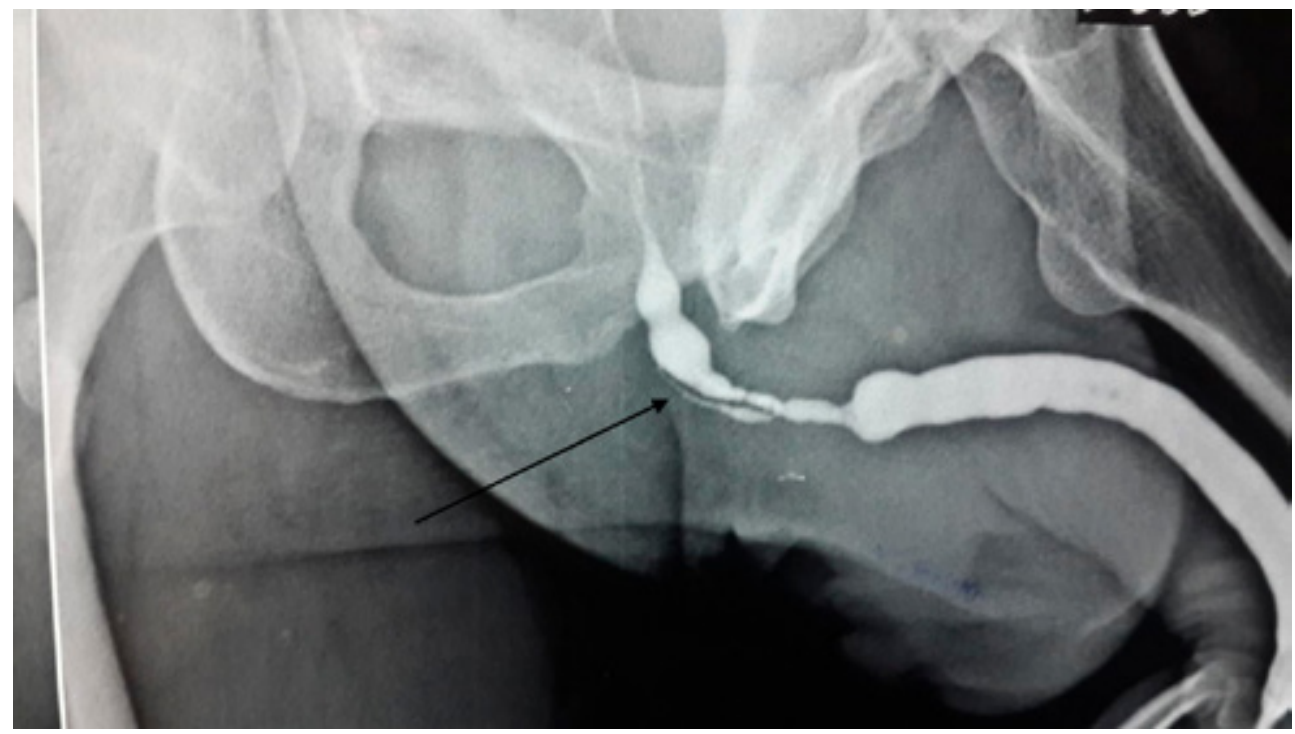


Figure 2. On MCU. Arrow shows post operative one side dorsal onlal buccal mucosal gaft urethroplasty in parrilla urethra

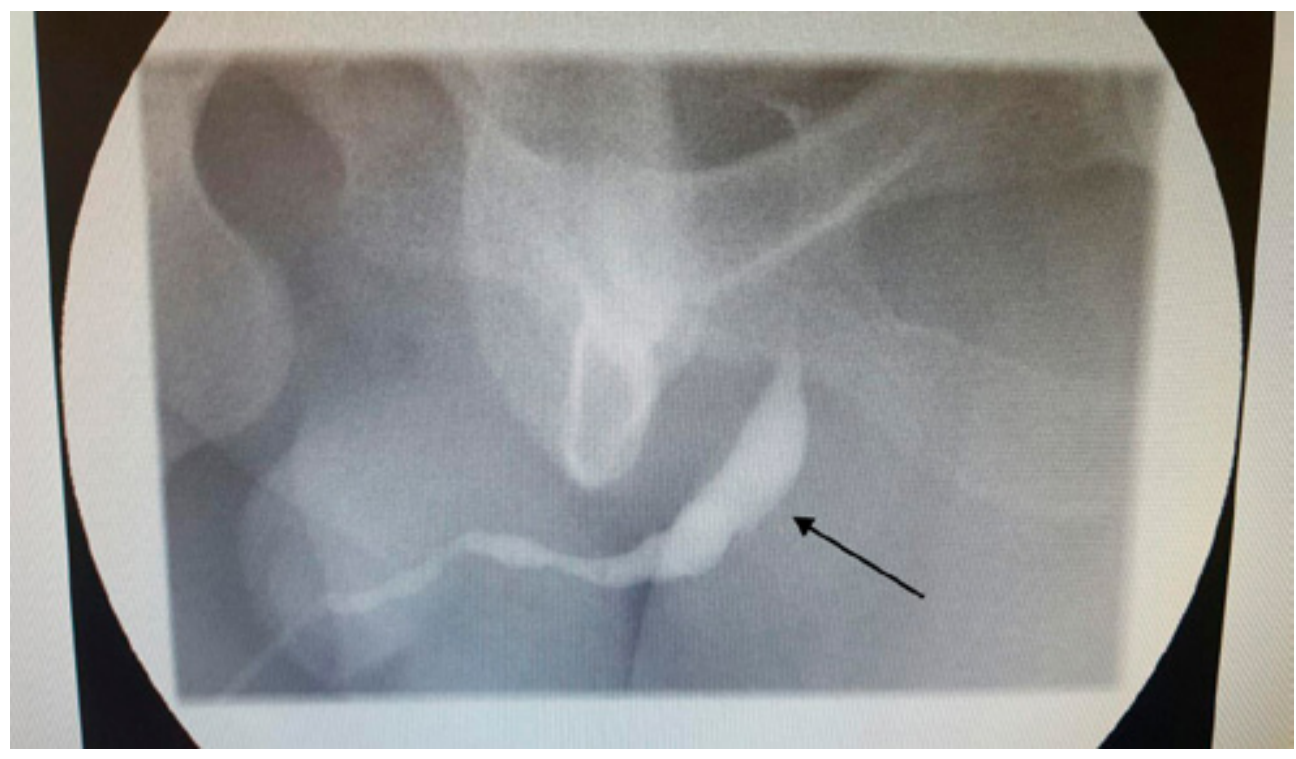

Table 1. Clinical Characteristic of the Patients ( $n=40$ patients)

\begin{tabular}{ll}
\hline & $\mathrm{N}=40$ \\
\hline Age (years) & $28-60 \mathrm{yrs}$ \\
Length of stricture $(\mathrm{cm})$ & $6.8(4-12)$
\end{tabular}

\section{RGU/MCU-site of stricture}

\begin{tabular}{ll}
\hline Bulbar & $22(55.0)$ \\
Penobulbar & $7(17.5)$ \\
Penile & $6(15.0)$ \\
PanUrethral & $5(12.5)$
\end{tabular}

Before surgery

\begin{tabular}{ll}
\hline Poor Urinary Flow & $40(100 \%)$ \\
Erectile Dysfunction & $40(100 \%)$ \\
$\quad$ - Severe (IIEF 5-7) & $12(30 \%)$ \\
- Moderate (IIEF 8-12) & $20(50 \%)$ \\
- Mild (IIEF 12-16) & $8(20 \%)$ \\
Painful Acute Urinary Retention & $28(70 \%)$ \\
Uncontrollable Urinary Loss & $16(40 \%)$
\end{tabular}

Table 2. GAF-Score

\begin{tabular}{rcc}
\hline $\begin{array}{c}\text { Pre-Surgery } \\
\mathbf{M}: \mathbf{4 7}\end{array}$ & $\begin{array}{c}\text { 6-12 m. } \\
\text { Post-Surgery } \\
\mathbf{M}: \mathbf{6 8}\end{array}$ \\
\hline $91-100$ & 0 & $7(17.5 \%)$ \\
$81-90$ & 0 & $8(20 \%)$ \\
$71-80$ & $3(7.5 \%)$ & $20(50 \%)$ \\
$61-70$ & $6(15 \%)$ & $5(12.5 \%)$ \\
$51-60$ & $11(27.5 \%)$ & 0 \\
$41-50$ & $20(50 \%)$ & 0
\end{tabular}

Chisq: $65.90, p<0.000$ 
order, and depressive disorder were observed amongst the victims who were referred for psychiatric/psychologist evaluation before management of urethral stricture disease (see table 1). This was in part secondary to torture and in part due to the presence of the suprapubic catheter, social isolation and continuous ammoniac smell of urine.

Patients with acute retention symptoms were initially managed by suprapubic catheterization (SPC) and drainage. All patients were later managed by substitution urethroplasty using oral mucosal graft placed dorsally after mobilization of urethra on one side only (Horiguchi, 2017) decreasing the urinary stream. Its surgical management is a challenging problem, and has changed dramatically in the past several decades. Open surgical repair using grafts or flaps, called substitution urethroplasty, has become the gold standard procedure for anterior urethral strictures that are not amenable to excision and primary anastomosis. Oral mucosa harvested from the inner cheek (buccal mucosa).

GAF scores measure the overall deterioration in functioning (see table 2). After urethroplasty none of the patients had to use a urobag. There were also improvements in erectile function. This is reflected in an overall improvement in GAF scores (Chisq: 65.90, df: $39, \mathrm{p}<0.000)$. We could not assess whether the improvement in overall well-being had an impact on primary PTSD and depression symptoms directly related to torture, although this seemed the case in conversations with the psychiatrist and psychologist where the patients were referred.

\section{Discussion}

The "parrilla urethra" (electric shock) is a torture method used to cause pain and fear without necessarily causing any immediate visible harm. The patients subjected to such torture complained of erectile dysfunction, dysuria and haematuria, difficulty in micturition as also reported by previous studies (Lunde I, 1992; Petersen et al., 1985). Electric shock torture to genitals is a predominantly physical torture method with both physical and psychological consequences, and with relentless long-term psychological sequelae (Araujo et al., 2019; Ba \& Bhopal, 2017; Miles \& Garcia-Peltoniemi, 2012). In Kashmir Valley, suicide seems a hidden consequence of the protracted conflict (Wani et al., 2011).

To the urologist, these patients present with predominantly obstructive voiding symptoms with associated poor self-esteem and psychological sequelae. There is, as such, a need for an interdisciplinary approach that is holistic and that addresses both mental and psychological well-being of both mind and body. Most of these patients were on urinary diversion in the form of suprapubic catheter (SPC) with an external urine collection bag (urobag) attached to it for collection of urine resulting in change in bodily image and a constant smell of urine. As a result, these patients prefer social isolation which leads to further deterioration of their social, physical and psychological wellbeing. Addressing the urological issues results in freedom from an SPC and consequent improvement in bodily image, which boosts self-esteem and confidence to socialise, thereby having a positive impact on overall wellbeing.

In the literature, the incidence of erectile dysfunction (ED) ranges from $20 \%$ to $84 \%$ in patients with urethral injury secondary to perineal trauma or pelvic fractures (Blaschko et al., 2015). ED caused by such trauma is due to lesions of the cavernous nerves or branches of the internal pudendal arteries that pass in close proximity to the pelvic bones and posterior urethra. The intimate relationship of the 
soft tissues and the bony pelvic ring result in a high risk of concomitant local injury associated with fractures of the pelvis. Even without severe urological injury, damage to the delicate vascular and nervous tissues supplying the genitalia can result in sexual dysfunction (Barratt et al., 2018).

In electric torture ("parrilla urethra") the erectile dysfunction is secondary to electric current injury and adds to the psychological consequences. Penile neurovascular tissue has the least resistance to current flow of all the tissues in the pubic area and is the most susceptible to damage with resultant neurovascular dysfunction and numbness of phallus. The electric current may result in coagulation of small vessels supplying the erectile tissue in addition to causing direct myogenic damage. We thus presume a multifactorial neurovascular and neuro-myogenic basis for erectile dysfunction in our sample of tortured patients.

In the majority of our cases the strictures were in anterior urethra likely due to the difficulty in negotiating bare wire through the anatomical course of bulbar urethra.

The urogenital problems were further compounded and complicated by neuropsychiatric sequalae of torture in our study group and patients were seen by psychiatrist during and after the treatment of urethral stricture. All the patients showed an improvement in GAF score after urethroplasty.

"Parrilla urethra" seems to be an appropriate term to define the urethra with sequalae of urethral trauma, particularly urethral stricture resulting from electric shock torture to genitals. The term will help to differentiate it from other aetiologies of urethral stricture.

\section{Limitations}

The sample size is low. We could not use psychometric measures of mental health changes and data is based on overall measures of well- being and clinical information from treating professionals. There is a need for prospective studies that carry out a pre-post measure of mental health impact, whilst distinguishing those impacts related to torture and those related to the psychosocial consequences of urethral stricture.

\section{Conclusion}

Survivors of electric shock torture to genitals often suffer from chronic debilitating urethral strictures with a poor quality of life and psychological distress, necessitating multidisciplinary and individualized treatment. The term "parrilla urethra" defines and differentiates these cases of urethral stricture disease from strictures from other aetiologies. Our study shows preliminary evidence that electric shock torture to genitals has devastating consequences on survivors and that addressing the physical consequences can ultimately improve the overall well-being of patients. Future studies need to address whether urethroplasty also has an impact on posttraumatic symptoms derived from torture.

\section{References}

Aas, I. H. M. (2011). Guidelines for rating Global Assessment of Functioning ( GAF ). Annals of General Psychiatry, 10(1), 2. https://doi. org/10.1186/1744-859X-10-2

Amnesty International. (1995). India. Torture and deaths in custody in fammu and Kashmir (ASA 20/01/95). https://www.amnesty.org/download/ Documents/176000/asa200011995en.pdf

Amnesty International. (1997). Arming the torturers: electro-shock torture and the spread of stun technology (ACT 40/04/97). London.

Araujo, J. de O., Souza, F. M. de, Proença, R., Bastos, M. L., Trajman, A., \& Faerstein, E. (2019). Prevalence of sexual violence among refugees: a systematic review. Revista de Saude Publica, 53, 78. https://doi.org/10.11606/s15188787.2019053001081

Ba, I., \& Bhopal, R. S. (2017). Physical, mental and social consequences in civilians who have experienced war-related sexual violence: a systematic review (1981-2014). Public Health, 
142, 121-135. https://doi.org/10.1016/j. puhe.2016.07.019

Barratt, R. C., Bernard, J., Mundy, A. R., \& Greenwell, T. J. (2018). Pelvic fracture urethral injury in males-mechanisms of injury, management options and outcomes. Translational Andrology and Urology, 7(29), S29-S62. https:// doi.org/10.21037/tau.2017.12.35

Blaschko, S. D., Sanford, M. T., Schlomer, B. J., Alwaal, A., Yang, G., Villalta, J. D., ... Breyer, B. N. (2015). The incidence of erectile dysfunction after pelvic fracture urethral injury: A systematic review and meta-analysis. Arab fournal of Urology, 13(1), 68-74. https://doi.org/10.1016/j. aju.2014.09.004

Crescenzi, A., Ketzer, E., Van Ommeren, M., Phuntsok, K., Komproe, I., \& de Jong, J. T. V. M. (2002). Effect of political imprisonment and trauma history on recent Tibetan refugees in India. Fournal of Traumatic Stress, 15, 369-375. https://doi.org/10.1023/A:1020129107279

Cunningham, M., \& Cunningham, J. D. (1997). Patterns of symptomatology and patterns of torture and trauma experiences in resettled refugees. Australian and New Zealand Fournal of Psychiatry, 31, 555-565.

Deol, S. S., \& Ganai, R. A. (2018). Custodial violence in Kashmir by the Indian security forces: A spontaneous consequence or a deliberate counter-insurgency policy? International fournal of Criminal fustice Sciences, 13(2), 370-384. https://doi.org/10.5281/zenodo.2657636

Dzhokic, G., Jovchevska, J., \& Dika, A. (2008). Electrical injuries: Etiology, pathophysiology and mechanism of injury. Macedonian fournal of Medical Sciences, 1(2), 54-58. https://doi. org/10.3889/MJMS.1857-5773.2008.0019

Gómez-Barris, M. (2009). Where memory dwells. Berkeley, Calif.: University of California Press.

Haq, I. (2017). Exploring the Concept of Torture: An Analysis of Kashmir Valley. SSRN Electronic fournal, 1-19. https://doi.org/10.2139/ ssrn.2954374

Haq, I. (2018). Torture in the Kashmir Valley and Custodial Deaths in India. Torture fournal, 27(3), 109-110. https://doi.org/10.7146/torture. v27i3.103972

Horiguchi, A. (2017). Substitution urethroplasty using oral mucosa graft for male anterior urethral stricture disease: Current topics and reviews. International fournal of Urology, 24(7), 493-503. https://doi.org/10.1111/iju.13356

Human Rights Watch. (1993). The Human Rights Crisis in Kashmir. https://www.hrw.org/sites/ default/files/reports/INDIA937.PDF
International Institute of Strategic Studies. (2019). Torture in Indian occupied Kashmir. http://issi. org.pk/report-roundtable-on-torture-in-indianoccupied-kashmir/

Iran Human Rights Documentation Center. (2011). Surviving rape in Iran's prisons. https://iranhrdc. org/surviving-rape-in-irans-prisons/

JKCCS. (2019). Torture. Indian state's instrument of control in indian administered famnu and Kashmir. http://jkccs.net/torture-indian-states-instrumentof-control-jammu-kashmir/

Lunde I, O. J. (1992). Sexual torture and the treatment of its consequences. In Torture and its Consequences- Current Treatment Approaches. (pp. 310-329). Cambridge University Press.

Masmas TN, Moller E, Buhmann C, Bunch V, Jensen JH, H. T. et al. (2008). Asylum seekers in Denmark- a study of health status and grade of traumatization of newly arrived asylum seekers. Torture, 18(2), 77-86.

Miles, S. H., \& Garcia-Peltoniemi, R. E. (2012). Torture survivors: What to ask, how to document. The fournal of Family Practice, 61(4), E1-E5.

Petersen, H. D., Abildgaard, U., Daugaard, G., Jess, P., Marcussen, H., \& Wallach, M. (1985). Psychological and physical long-term effects of torture. A follow-up examination of 22 Greek persons exposed to torture 1967-1974. Scandinavian fournal of Social Medicine, 13, 89-93.

Rosen, R., Cappelleri, J., Smith, M. et al. (1999). Development and evaluation of an abridged , 5-item version of the International Index of Erectile Function ( IIEF-5) as a diagnostic tool for erectile dysfunction. International fournal of Impotence Research, 11, 319-326. https://doi. org/10.1038/sj.ijir.3900472

Rosen, R. C., Riley, A., Wagner, G., Osterloh, I. H., Kirkpatrick, J., \& Mishra, A. (1997). The international index of erectile function (IIEF): a multidimensional scale for assessment of erectile dysfunction. Urology, 49(6), 822-830. https://doi. org/10.1016/S0090-4295(97)00238-0

Rybarczyk, M. M., Schafer, J. M., Elm, C. M., Sarvepalli, S., Vaswani, P. A., Balhara, K. S., .. Jacquet, G. A. (2017). A systematic review of burn injuries in low- and middle-income countries: Epidemiology in the WHO-defined African Region. African fournal of Emergency Medicine, 7(1), 30-37. https://doi.org/10.1016/j. afjem.2017.01.006

Suhaiban, H. A., Grasser, L. R., \& Javanbakht, A. (2019). Mental health of refugees and torture survivors: A critical review of prevalence, predictors, and integrated care. International 
Fournal of Environmental Research and Public Health, 16(13). https://doi.org/10.3390/ ijerph 16132309

Tahir Tabassum, M. (2012). Political Situation in Kashmir and Role of the United Nations. SCS fournal, 1(2), 4-28.

Tamblyn, J. M., Calderon, A. J., Combs, S., \& O'Brien, M. M. (2011). Patients from abroad becoming patients in everyday practice: Torture survivors in primary care. Fournal of Immigrant and Minority Health, 13(4), 798-801. https:/doi. org/10.1007/s10903-010-9429-2

UN General Assembly. (1984). The Convention Against Torture and other forms of cruel, inhuman and degrading treatment or punishment. 10 December 1984. OHCHR. https://www.ohchr.org/ en/professionalinterest/pages/cat.aspx

Villani, M. (2011). Desaparecido. Memorias de un cautiverio. Club Atlético. El Banco, El Olimpo, Pozo de Quilmes y ESMA. Biblos.

Wani ZA, Hussain A, Khan AW, et al. (2011). Are health care systems insensitive to needs of suicidal patients in times of conflict? The Kashmir experience. Mental Illness, 3, 11-13.

Weishut, D. J. N. (2015). Sexual torture of Palestinian men by Israeli authorities. Reproductive Health Matters, 23(46), 71-84. https://doi.org/10.1016/j. rhm.2015.11.019 